\title{
Challenges and Needs for Support in Managing Occupational Health and Safety from Managers' Viewpoints
}

\section{Sari Tappura'}

Doctoral student, Center for Safety Management and Engineering, Industrial Management, Tampere University of Technology, Finland

\section{Sirpa Syvänen}

Adjunct professor, School of Management and Work Research Centre, University of Tampere, Finland

\section{Kaija Leena Saarela}

Professor, Center for Safety Management and Engineering, Industrial Management, Tampere University of Technology, Finland

\begin{abstract}
Proper working conditions and successful occupational health and safety (OHS) management help organizations achieve their targets and support the quality of working life and performance. Work-related stress, conflicts, work ability issues, ill health, and other challenging OHS situations in the workplace may impede the well-being and productivity of employees. According to OHS legislation, employers are responsible for managing risks and solving problems in the work community. Challenging situations can be viewed from the perspective of efficiency, since their economic effects may be remarkable.

The objective of this study is to describe the challenging OHS situations managers encounter and the support they require in these situations. The results are based on thematic interviews and inquiries with top, middle, and front-line managers in three Finnish public sector service organizations. The most challenging OHS management situations are related to the administration of work under high economic pressure and constant changes in the work community, managing employee workload and time pressures, providing feedback, facilitating collaboration, and managing conflict. The managers' own understandings, competences, and resources, as well as organizational supports, have an effect on successful resolutions of challenging OHS management situations.
\end{abstract}

\section{KEY WORDS}

Occupational health and safety / manager / psychosocial work environment / efficiency

\section{Introduction'}

ccupational health and safety (OHS) research addresses the essential role played by managers in improving employee health and safety at work, because they plan and lead as well as manage the OHS of production (e.g., DeJoy et al. 2004; Flin et al. 2000; Hale et al. 2010; Hofmann and Stetzer 1996; Zohar 2002). Thus, at all

\footnotetext{
${ }^{1}$ E-mail: sari.tappura@tut.fi
} 
organizational levels, managers play an essential role when striving for the development of OHS in organizations. According to research (e.g., Conchie et al. 2013; Frick 2013; Hardison et al. 2014; Simola 2005; Tappura and Hämäläinen 2012), managers' own resources, competences, and commitments, along with their organizational environments and supports, are important to the successful establishment of OHS standards. At the organizational level, the management of OHS means enforcing systematic and formalized principles and procedures to improve OHS (e.g., Bluff 2003; Frick and Wren 2000; Frick et al. 2000; Gallagher et al. 2001; OHSAS 18001:2007; Saksvik and Quinlan 2003). OHS management is based on regulations (D 89/391/EEC; L 23.08.2002/738) and voluntary forms, such as standards and guidelines for OHS management systems (e.g., Bluff 2003; Gallagher et al. 2001; OHSAS 18001:2007). In this study, organizational OHS procedures refer to regulatory procedures, whereas other organizational procedures refer to voluntary procedures.

In recent decades, the organization, management, and nature of work have changed, resulting in emerging OHS risks, such as those that are psychosocial, and mental and emotional demands have increased (EU-OSHA 2007; Leka et al. 2011; Siegrist et al. 2004; Työterveyslaitos 2013). Psychosocial risks, such as work-related stress, violence, bullying, harassment, and unsolved conflicts, are widely recognized as major challenges to OHS, weakening occupational health and well-being as well as organizational performance (e.g., EU-OSHA 2007; Eurofound 2010; European Foundation 2007; Leka et al. 2011). According to the European Foundation (2007), work-related stress is one of the most commonly reported reasons for absence from work. Psychosocial hazards threaten employee health but also influence accident causation and occupational injuries (e.g., Bonde 2008; Clarke 2010; Clarke and Cooper 2004; De Jonge et al. 2000; Godin and Kittel 2004; HSE 2007; Karasek et al. 1981; Leka et al. 2011; Lundberg and Melin 2002; Sutherland and Cooper 1991; Theorell and Karasek 1996; Vahtera et al. 2000). Moreover, Law et al. (2011) found a significant relationship between adverse psychosocial work environments (PSWEs), including those featuring inappropriate behaviors like bullying and harassment, and related psychological health problems. At the same time, managers often work under conflicting pressures brought on by a continual sense of urgency, an excessive workload, conflicts in the work community, fragmented work, organizational confusion, and constant pressure to improve productivity and performance, achieve cost savings, and implement changes (e.g., Björk et al. 2014; Syvänen 2010; Syvänen and Kokkonen 2011; Työterveyslaitos 2013).

The focus of this study is on managing OHS when striving for a safe, healthy, innovative, and high-performance working environment. However, due to the nature of the participating organizations, the psychosocial aspects of OHS management are emphasized. This study is conducted in the public service sector, where the PSWE significantly influences the OHS of employees. However, in the public sector, employees generally work on variable tasks and they are exposed to nearly all types of OHS risks (Frick 2013). This study presents an example of the employer's role in improving the working environment of the public service sector.

The main objective of this study is to describe the challenging and difficult OHS situations managers encounter and the support they experience and require during these situations. Moreover, the employer's regulatory OHS responsibilities are discussed, the economic effects of OHS are considered, and suggestions for motivating employers to improve OHS are presented. The study also discusses the importance of 
supporting managers as representatives of employers in an effort to ensure favorable OHS conditions.

This study is a part of the Finnish multidisciplinary research program called Dialogic leadership promoting innovativeness (Dinno) 2012-2014, and it is funded by the Finnish Funding Agency for Innovation (Tekes). It focuses on managers' dialogic skills in support of innovation activities. In particular, the perspective is focused on challenging leadership situations that may reduce the quality of the work environments, innovativeness, and performances of organizations. The theoretical framework of Dinno argues that a dialogic leadership approach provides a positive influence through internal motivation, dialogue, collaboration, and transformational learning in terms of creativity, competence, innovativeness, quality of working life, and performance (Syvänen et al. 2012). The central areas of dialogic leadership are communication of organizational goals, values, procedures, and rules, as well as feedback, support, trust, safety, appreciation, collaboration, transformation, and conflict management (Syvänen 2014a, 2014b).

First, the relevant employer OHS responsibilities, due to the regulations and current research on the quality of working life, are considered based on literature in order to describe the challenges employers, and managers as their representatives, encounter. Second, the economic effects and costs of the internal inefficiency of OHS deficiencies are discussed to identify the importance of OHS development from the perspectives of performance and efficiency. Third, the challenging and difficult situations and the need for manager support during such encounters are presented based on an empirical study. The results are based on the qualitative data of thematic interviews and inquiries with 72 managers in three Finnish organizations. The organizations comprise a governmental expert organization, municipal social and health care service units for the elderly, and a vocational educational organization. The psychosocial aspects of OHS are emphasized in the theoretical section and they are discussed in comparison with the physical aspects due to the nature of the organizations' sector, the focus of this study, and the empirical results.

\title{
Employer perspective on OHS management and its challenges
}

In and since the 1970s, the Nordic OHS regulations have changed

\begin{abstract}
'from a descriptive (extensional) definition of occupational health and safety as a gradually increasing list of risk factors to a more principal (intensional) definition of the work environment as every aspect of work and its conditions that may affect workers' health' (Frick 2013; see also Bluff 2003; Frick and Wren 2000).
\end{abstract}

Since the 1970s, Nordic countries have also pioneered psychosocial requirements in the form of legislation (Frick 2013). In Europe, the OHS Framework Directive (D 89/391/ EEC), as well as further OHS directives, is the fundamental of health and safety legislation. In Europe, the psychosocial aspects of the work environment have been regulated through the Framework Directive (Bruhn and Frick 2011) and regulations actually require employers to respond to work-related psychosocial risks (Ertel et al. 2008). Ever since, the OHS regulations have put an increased strain on employers and PSWEs. 
However, recent findings suggest that OHS legislation is not very effective for the management of psychosocial risks (Leka et al. 2011; Natali et al. 2008).

In Finland, the Framework Directive has been transposed into the Occupational Safety and Health Act (L 23.8.2002/738) and its supplementary regulations. OHS regulations state the requirements for employers and employees. In this article, the focus is on the employers' responsibilities and on the managers' role as representing the employer. According to the Act (L 23.8.2002/738), the employer shall take care of the health and safety of his or her employees while at work and improve the working environment and conditions accordingly. The employer shall have OHS procedures in place for continuous monitoring of the working environment as well as systematic hazard identification, risk assessment, and risk reduction. Hazards include both physical and psychosocial dangers in the work environment. Psychosocial risks include the design and management of work and its organizational contexts that have the potential to cause psychological or physical hazard (Cox and Griffiths 2005). They are linked to work-related stress, as well as workplace violence, harassment, and bullying (EU-OSHA 2007). High strain and psychological demands (high demand) with low decision latitude and personal freedom (low control) are associated with ill health (e.g., emotional exhaustion, psychosomatic health complaints, and cardiovascular diseases) (e.g., et al. 1982; De Jonge et al. 2000; Karasek et al. 1981; Kivimäki et al. 2006; Theorell and Karasek 1996). Moreover, work-related stress influences accident involvement, affecting employee behavior either directly or indirectly via psychological and physical strain (Clarke and Cooper 2004). For example, hurrying, the need to save time, tight schedules, and a related lack of caution have great influences on accidents (Salminen et al. 1993; Tulonen 2010). The reasons for hurrying are most often related to organizational problems, e.g., the planning and execution of tasks (Syvänen and Kokkonen 2011; Tulonen 2010).

The employer has a responsibility to promote good relations with and among employees, which means improving collaborations as well as encouraging a good atmosphere and appropriate interactions in the work community. Employers are also responsible for actively solving problems in the work community. For example, when harassment or other inappropriate forms of employee treatment occur and cause risks to the employees' health, the employer shall take any remedying measures (L 23.08.2002/738). If necessary, the manager has-due to his or her directive position-both the power and the duty to take the necessary actions. However, in reality, many managers lack such power because upper management personnel often ignore their legal duty to manage risks and delegate PSWE issues to first-line supervisors, without providing any resources, support, guidance, or monitoring the results (Frick 2013).

The organizational OHS procedures (L 23.08.2002/738) should support managers in their ability to focus on the psychosocial risks in their workplace, since their origins are often at the organizational level (Cox and Griffiths 2005; Idris et al. 2012). The psychosocial risks are often related to an imbalance between workload and time, as well as problems of relations, leadership, and trust. These are mostly high-level issues, and front-line managers can do little to resolve them (Frick 2013). According to studies conducted by Hasle et al. (2008) and Saksvik et al. (2002), a clarification of the roles and responsibilities of middle management, multilevel participation, and the continuous support of top management are critical to success, especially in stress management interventions. According to Finnish studies (Syvänen 2010; Syvänen and Kokkonen 2011; Tappura and Hämäläinen 2011), managers often perceive psychosocial issues as being 
difficult and feel their competence is inadequate. Thus, effective organizational interventions are required to support managers and to develop and implement procedures that protect the psychological health and safety of employees (Law et al. 2011).

\section{Organizational economic perspective on challenging OHS management situations}

The performance and competitiveness of an organization depend on its ability to produce products or services effectively and to efficiently transform ideas into new products, services, and work processes. The outlook of future working environments emphasizes the competence and cooperation of employees and organizations in continuously changing circumstances and environments (Työterveyslaitos 2013). Developing occupational well-being should focus on strengthening employee resources and work communities.

OHS issues are increasingly associated with the operational efficiency and competitiveness of organizations (Boyd 2003). For example, when an organization has a high frequency of accidents, maximally effective productivity and quality are unlikely (Carder and Ragan 2003). In addition, Köper et al. (2009) studied OHS links to overall business issues (performance and competitiveness), and the results of their study support a correlation between health-related issues and organizational performance, whereas adverse work conditions affected business issues negatively. Thus, managing OHS is a part of managing other business activities, and OHS issues should be closely integrated into general management processes (e.g., Bluff 2003; EU-OSHA 2010). According to Leka et al. (2011), best practices in relation to psychosocial risk management essentially reflect best practices in terms of good work, organizational management and development, social responsibility, and the promotion of a quality of working life.

From an organizational economic perspective, developing OHS has a positive influence on, for example, decreased absenteeism and presenteeism, work-related early retirements, and occupational injuries, and it increased working capacity (e.g., Berger et al. 2012; Clarke and Cooper 2004; DeRango et al. 2003; Hlobil et al. 2007; Nelson et al. 2006; Sievänen et al. 2013; Syvänen 2010; Yeow and Sen 2003). According to a recent review (Tappura et al. 2014), the reported economic evaluations of OHS interventions are usually related to ergonomic interventions, and their financial results are typically positive. In addition to OHS cost savings, developing OHS has the potential for even greater economic benefits through the influence of increased work capacity and its effects on productivity (e.g., DeRango et al. 2003; Niemelä et al. 2002; Sievänen et al. 2013; Tappura et al. 2014).

Internationally, the total costs of occupational accidents and work-related diseases have been approximated to $4 \%$ of the gross national product (Safety in numbers 2003). In Finland, the estimated value of work-related OHS costs is $€ 40$ billion per year (Työterveyslaitos 2013). Work-related stress accounts for a high proportion of illnessrelated absences due to, for example, mental, cardiovascular, and musculoskeletal symptoms (e.g., Alfredsson et al. 1982; Bonde 2008; Godin and Kittel 2004; Karasek et al. 1981; Kivimäki et al. 2006; Lundberg and Melin 2002; Theorell and Karasek 1996). It is estimated that $40-60 \%$ of all work absences are stress related (e.g., Earnshaw and Cooper 2001; Schabracq et al. 1996), and that occupational stress is involved in 60-80\% of work accidents (Sutherland and Cooper 1991). 
Difficult and challenging OHS management situations and deficiencies in PSWE can also be seen from the perspective of internal inefficiency (Leibenstein 1987; Syvänen 2010) or organizational slack (e.g., Bourgeois 1981; Leibenstein 1969; Singh 1986), resulting from an organization's failure to meet the full potential (quantity and quality) of its available resources. Different problems associated with individual-, group-, and organizational-level factors potentially undermine the efficiency of an organization. These include the individual features of the work (work load, pace, quality, and timetable), work effort, under- and overload, problems with work control, individual work behaviors, and group function, interaction, cooperation, management, and leadership (e.g., Alfredsson et al. 1982; Frantz 1990; Karasek et al. 1981; Leibenstein 1987; Siegrist et al. 2004; Theorell and Karasek 1996; Tomer 1987; Syvänen 2010). Due to these problems, efficiency remains below maximum, and internal inefficiency is present in the organization and in production processes.

In addition to regulatory duties, the employer should also minimize the time and effort employed in processing PSWE problems and conflicts due to the productivity demands (e.g., Clarke and Cooper 2004; Leka et al. 2011). Deficiencies in PSWE are connected to conflicts, such as bullying and harassment (e.g., Law et al. 2011). According to Järvinen (1998), organizational conflicts can be divided into four main groups: (1) conflicts related to crisis and change situations; (2) conflicts related to stress and burnout; (3) problems stemming from individuals; and (4) collaboration problems and crises. At best, organizational conflicts can work as engines and resources for creativity, renewal, and collaboration (George 2008), but too often, conflict is considered a negative phenomenon.

Employers must have systematic OHS procedures in place to assess and reduce risks (including risks related to PSWE) and actively solve conflicts (L 23.08.2002/738). In addition, from a performance point of view, determining how these conflicts are resolved and what kinds of procedures are in place for active conflict resolution is crucial (Syvänen 2010; Syvänen and Kokkonen 2011). Unresolved conflicts generate costs due to increased stress, frustration, and anxiety, as well as sleeping problems, mistakes, accidents, long and short sickness leaves, premature retirement, and job changes (e.g., Clarke and Cooper 2004; Dana 2001; Earnshaw and Cooper 2001; Schabracq et al. 1996; Sutherland and Cooper 1991). Thus, the costs associated with PSWE-related illnesses and accidents are enormous, and successfully managing PSWE risks highly benefits organizations (e.g., Clarke and Cooper 2004; Dana 2001).

A safe, positive, and supportive working environment is also crucial when striving for product, service, and work process innovations (e.g., Amabile 1997; George and Zhou 2007). An open, confidential, and psychologically safe work environment encourages employees to express critical feedback (Detert and Burris 2007). This leads to new ways of problem solving and thus fosters transformation and creativity (George 2008). At the same time, all kinds of conflicts, acts of negligence, work ability issues, work-related illnesses, and other challenging situations in the workplace may impede the well-being, creativity, performance, and, especially, productivity of employees (e.g., Amabile et al. 2004; Clarke and Cooper 2004; George and Zhou 2007; Syvänen 2010). According to Nielsen et al. (2010) review, communication, and a collaborative climate are central elements when struggling to improve the psychosocial environment of a workplace. 


\section{Methods and participants}

The empirical part of this study is based on thematic interviews and inquiries with top, middle, and front-line managers in three Finnish organizations. The research data consist of managers' interviews and qualitative answers to inquiries in three public sector organizations (a governmental expert organization, municipal social and health care service units, and a vocational education organization) participating in the Dinno research program (Syvänen et al. 2012).

Due to the nature of the study, the methodology of phenomenology (Patton 2001) was selected as the theoretical framework for the qualitative analysis. It is a particularly suitable vehicle for seeking answers to the research question of this study. In a phenomenological analysis, the basic concepts of the theoretical framework provide a welldefined viewpoint through which the entire data are reviewed and arranged, and through which irrelevant data are screened out. In a qualitative analysis, the main categories are formed by means of the basic concepts, and subcategories emerge according to the specific features of the data. The objective of the qualitative research was to understand the challenges and difficult situations managers encounter. A qualitative analysis progresses from details to a general level, and through this progression, collective features are sought from the individual experiences. In the analysis of qualitative data, the main stages of phenomenological analysis (Patton 2001) were followed, with the researchers modifying them to some extent. The qualitative analysis is based on original material from the research sites.

A total of 72 managers from different levels (e.g., directors, senior nursing officers, head nurses, head counselors, heads of educational programs, HR managers, group managers, line supervisors, and planning directors) participated in the study. Included were both experienced and novice managers, with their supervisory experience varying between 1 and 30 years.

The interviews were conducted in autumn 2012 and focused on the governmental expert organization (about 200 employees), which experienced major organizational changes in 2011 and a related unification of management procedures ever since. Economic pressure was high due to the Finnish public sector productivity program. In the expert organization, work is oriented toward high results and complex problem solving in various fields of expertise (e.g., chemicals, construction products, electrical equipment, measuring instruments, and pressure equipment). The interviews were part of a larger interview study on managers' OHS management competences, conceptions, and realization as a part of the Dinno program (see Tappura and Syvänen 2013a, 2013b). The interviewees were chosen based on their managerial role: all 18 group managers of the organization were invited to participate in the study. In total, all but one participated and 17 interviews were conducted successfully. There were eight female and nine male interviewees, who were the immediate superiors of the experts in their group. The interviews were semistructured, and one pilot interview was conducted to test the interviewer guidelines. One researcher conducted all the interviews, which were recorded and transcribed.

The inquiries focused on six social and health care organizations providing services for the elderly (about 1,100 employees) as well as a vocational education organization (about 1,050 employees). The inquiries were conducted using the digital Webropol survey tool in 2013. In both organizations, collaborative and dialogic action research 
projects were carried out between 2012 and 2014. Inquiries were made with the managers prior to the commencement of the development projects in order to determine the features of leadership and management as well as the challenges and support needs. Invitations to answer these inquiries were sent to 76 managers and 55 answers were received, where 31 female and 15 male answerers disclosed their sex and 9 did not.

The results of this article are based on the following research questions:

- From the managers' perspectives, what kinds of situations and matters related to OHS management do they feel are particularly difficult?

- From where do the managers receive support for these situations?

- What kind of support do the managers expect and need to help them in managing OHS?

First, the qualitative data of the interviews and inquiries were analyzed and thematically classified separately by the two researchers. Second, the results of both the interviews and inquiries were conjoined and then categorized under thematic result categories. Interpretations of the results and the discussion are based on the selected perspectives and emphases in accordance with the nature of the participating organizations and the theoretical framework of this study. The effects of difficult situations and the lack of support experienced by the managers are discussed, as well as the managers' needs for support and organizational means to achieve resolution, which will aid them in their challenging roles. The focus is not on the managers' own well-being, although support in the managerial role helps them to cope with their own tasks better.

\section{Results}

\section{Challenging OHS management situations in supervisory work}

Different kinds of OHS-related management situations were perceived as being difficult among the respondents, especially when occurring for the first time. Some issues had been dealt with in previous management training, but when such incidents occurred, the training was not current and the manager had not learned the lesson. When a challenging situation occurred, the managers typically looked for ad hoc help from their superiors, colleagues, HR experts, and OHS experts to manage the situation. They also expected emotional support and to be able to share the experience confidentially with colleagues. The managers did not mention financial support from upper management, although more resources would help them in organizing the work. The results were categorized according to the following thematic categories.

\section{Administration}

The high economic and efficiency pressures and the lack of resources in relation to targets were found to be the most significant factors affecting managers' abilities to design and administer work. In addition, the constant changes within the work community negatively affected managers' abilities to support employee well-being and to 
cope with their workload. Almost all managers in all of the studied organizations felt it was challenging to comply with the bureaucracy and rules of a large organization, especially at times of major change and economic cutbacks. Decision-making, explaining the decisions to the staff, operational planning and organization, enforcing common rules, agreeing on common policies, and implementing assertive operational methods were considered difficult tasks.

'It's hard to keep people happy in an environment of constant change and motivate them to be enthusiastic about new challenges and procedures when resources are being cut.'

Managers experienced multiple conflicting pressures, organizational confusion, and incompleteness of organizational structure, and they found economic changes to be stressful and complicating to their work. These factors created fragmentation and confusion in their position as well as their overall work and responsibilities. In other words, power and responsibility did not match.

'Impossible deadlines, pressures from subordinates, supervisors, the field, colleagues, myself, the society, students-bringing these together.'

'The problem is the extent of my job description: the playing field is not clear at the moment, and that's why one's own matters are left unattended [...] The extent and lack of definition of duties.'

'What's difficult is the impact of temporary and permanent redundancies and the number of staff available.'

Almost every manager highlighted cooperation procedures related to redundancies as the most difficult and challenging part of their work, especially regarding its effects on staff and operations.

'When it's on, co-operation negotiation always puts pressure on a supervisor's work. It's really tough that the numbers and euros play such a big role in these situations.'

'Reorganization of work that comes with organizational change is challenging when the headcount's smaller.'

Nevertheless, everyone understood that the changes were necessary for the organization and they were imposed on them as a consequence of governmental decisions.

\section{Support for managing workload, evaluation of workload, and prioritization}

The respondents felt it difficult to plan and design the workload of the employees in ways that were fair and balanced, especially when everybody had ample work and pressure. They found it difficult to evaluate and prioritize the workload in this situation. At the same time, they recognized that the workload should be individually tailored to suit every employee. They felt that taking into account individual factors and burdens 
caused by employees' life situations, health, and personal matters (e.g., active support at different stages of life, ageing, the busiest time in life when children are small or personal issues) are difficult situations. The respondents also felt difficulty evaluating the deterioration of an individual's ability to work or perform at work and the need for intervening (e.g., tailoring workloads for employees with a reduced work capacity or organizing a lighter workload).

'What's difficult [] is a fair allocation of work according to the individual employee's ability to work and organizing a lighter workload.'

'People with lots of unprocessed traumatic background and with lots of challenges on the home front find it difficult to cope with workload and can't be well at work, either.'

The respondents felt that one important and difficult area was the evaluation and management of mental and physical overload related to hurrying and work pressures. They had little means to assess their employees' burdens, particularly if employees did not disclose details of their own initiative. Furthermore, if they did disclose, managers had little or no means to solve the work pressure due to limited resources. Often, the managers were concerned with their subordinates' well-being but could not help them due to the lack of organizational support.

There was a constant need for prioritization and discussion about what should be done by whom and whether something could be left undone in order to improve the control of employees over their own jobs. The managers believed that it was important to support this control, but they did not have enough time to deal with their employees individually in this area or to be present and available in the midst of their own time pressures and hectic daily work. The respondents also considered it difficult to listen and find a common language when communicating with their employees. They felt that a lack of discussion opportunities was an obstacle to openness and was due to, for example, a lack of time.

\section{Feedback}

Many supervisors considered giving any kind of feedback-positive, encouraging, critical, negative, or constructive-difficult. They felt that because they did not always remember to give feedback or did not find the time, opportunity, or appropriate situation for it (lack of time, urgency, hectic schedules, impossible schedules, and not being present or available) they were prevented from providing feedback. Providing constructive feedback was considered particularly difficult among managers in social services, health care, and educational organizations. They mentioned, for example, having trouble providing feedback related to shortcomings and errors in work performance and other problems or inappropriate behavior. The difficulties in providing constructive feedback reflect the generation of conflicts and problems in their management performances.

\section{Social relations and interaction}

As examples of difficult situations, the respondents cited the characteristics of supervisory work that are related to collaboration and social interaction relationships and the 
corresponding skills and competencies. Shortcomings were pinpointed to the interaction skills, emotional intelligences, and social skills of managers as well as employees. Some supervisors mentioned it was hard to change the prejudicial interactions despite development activities (e.g., individual discussions). Furthermore, collaboration may also deteriorate if all employees do not actively participate in development meetings.

\section{Conflicts}

The primarily difficult conflicts and their related shortcomings experienced by the supervisors in the studied organizations followed the classification of Järvinen (1998): (1) conflicts in crisis and change situations; (2) conflicts related to stress and burnout; (3) problems stemming from individuals; and (4) collaboration problems and crises.

1 Conflicts caused by change situations and crises: cooperation negotiations/processes, economic cutbacks, mergers, changes to job descriptions, changes to power and responsibility relations, termination of services and functions, work communities in crisis with multiple conflicts, strong personalities, aggressions, or other forceful emotional expressions.

2; 3 Conflicts related to stress or work underload or overload, as well as problems stemming from individuals: difficult personalities, conflicts with one's own superior, intervening in situations with inappropriate behaviors, disciplinary situations, unauthorized absences, and a noncommitment to work, the work community, its rules, and its clients.

4 Problems and conflicts of collaboration: difficult interrelations in the work community, organization-wide conflicts, conflicts between employees.

The most challenging and difficult managerial situations from an employer's perspective exist in the presence of workers with difficult personalities and in dealing with their inappropriate and unprofessional behaviors. Difficult issues in the area of conflict management on the individual level include providing negative feedback, solving disagreements between employees, intervening in unpleasant, difficult, and complicated matters, indicating appropriate work behavior, solving individual employee problems that affect their work, disciplinary matters (e.g., reprimands, cautions, and terminating employment contracts), and instructing or ordering compliance with common rules and agreements.

'People who, time after time, despite active and appropriate intervention, don't comply with common rules: that's frustrating.'

The managers gave varying descriptions of what kind of work behavior they found the most difficult to encounter and deal with.

'Can't think of a specific personality type to be avoided. It's more about situations that you [yourself] feel are difficult.'

'It's hardest to encounter people who are different from me: they challenge my own weaker sides.' 
'People who are silent, closed, or shy or don't voice their views are difficult to deal with. With them, you never know whether something is good or bad. Also, their potential skills and ideas are lost in the lively interaction of the others.'

The respondents pointed out the importance of actively solving problems and that the work community should be open and willing to confront difficult issues and find solutions. According to the managers, they should actively raise conflict awareness and discuss the situations with the work community to clear the air and focus on work.

\section{Experienced and expected support needs}

The managers in all the organizations studied-on all levels and in different positionswere highly strained, required competence, and expected support in coping with their own workloads, leadership duties, and the different challenging situations in the work community. First, they expected support from their own superiors. For some managers, a lack of support or appreciation from their superior, distance, or conflicts with their superior hindered both their own occupational well-being and productivity and that of the entire unit or department. The lack of such support was balanced by the support of, for example, colleagues, families, and friends, but they could not replace the needed workplace support completely. A manager's superior is expected to point the way; be realistic, open, and appreciative; conduct discussions; listen; be present; provide feedback and support; encourage and collaborate; trust; be reliable; and provide freedom, autonomy, and encouraging and constructive feedback. One of the respondents mentioned that, in a difficult situation, he 'goes and cries on the supervisor's shoulder', and it helps.

In addition to their immediate superior, the respondents considered the support of their colleagues within and outside of their own organization to be important. Support from colleagues (other managers) was considered important, especially when encountering a difficult situation for the first time. The respondents felt that it was good that they were able to discuss difficult situations confidentially, exchange experiences and opinions, and learn solutions from their colleagues. Respondents considered 'colleague talk' to be encouraging and motivating. The managers did not place as much importance on formal peer support and peer mentoring; instead, they sought to discuss matters ad hoc with the right people to obtain peer support and share experiences. It was important and sufficient that the colleagues had time to listen and that they understood the situation and the emotions caused by it. Also mentioned as sources of support were the managing group or board of their own unit or department, with whom difficult and private issues may be discussed confidentially. In some cases, their own subordinates supported and encouraged managers to find solutions to difficult situations.

The managers needed support mainly in handling difficult and problematic situations and in solving conflicts. The managers expressed a desire to share, talk, discuss, and reflect on, through occupational counseling, the situations and matters they considered difficult and burdensome (e.g., encountering strong emotional reactions, the balance between power and responsibility, loneliness in making difficult decisions, and solving persistent problems in the workplace). This kind of support was expected from occupational health care as well as HR experts, colleagues, family, and friends. 
The supervisors called for more training, individual support in coping with their own managerial work, opportunities for counseling, and discussion about the organizational policies and procedures at the managing board level. The respondents hoped that such discussions would bring clarity, a systematic approach and argumentation, and a foundation for their own decision-making in their area of responsibility. Respondents felt that organizational clarity strengthens the experience of being in control of their own work and coping amidst many pressures. They also called for harmonized organizational procedures and strengthening skills in the areas considered to be difficult (e.g., managing mental work load, inappropriate work behavior, and conflicts). Examples of the mentioned organizational supports include definitions of their mandate and responsibilities, collective rules (e.g., for appropriate work behavior), intervention procedures, sanctions from violating the directions, remote work agreements, models of early intervention and support, or department meetings and development days.

\section{Discussion}

This study described the range of challenging and difficult OHS management situations the respondents experienced, as well as the support that they expected in these situations. The information was compiled through interviews and qualitative inquiries into three organizations from the public service sector, similar to Frick's (2013) study that focused on a school and two home care groups for the elderly. The challenging situations cited were mainly related to PSWE issues, due to the nature of the research sites. Framing of the interview questions may also have affected the answers; the managers were asked about challenging situations, which may be more associated with psychosocial than traditional OHS issues.

The problems identified are important because they are part of the employer's regulatory OHS responsibilities. They are also highly related to the operational efficiency, quality of working life, creativity, and competitiveness of an organization (e.g., Amabile 1997; Boyd 2003; Carder and Ragan 2003; Clarke and Cooper 2004; George 2008; Köper et al. 2009; Syvänen 2010).

Due to the current economic and efficiency pressures and lack of resources, both managers and employees often experience large workloads, which is a major OHS problem (see Frick 2013). However, the managers did not call for more resources or support from upper management, presumably due to the tight economic situation. They mostly focused on individual relations and emotional support to cope with the challenging situations. According to the experiences of the managers, the most challenging OHS management situations are related to the psychosocial risks in the work community. Traditional OHS issues, such as physical risks, were not seen as challenging, mainly because there are procedures to manage them. Presumably for the same reason, bullying and harassment were not cited as the most challenging OHS issues, either. For example, employees' mental overloads, instances of negligence, and considering individual characteristics and needs are highlighted as challenging situations. In addition, employees' personal problems are considered difficult to manage. Quite surprisingly, many managers considered giving any kind of feedback difficult, including positive. However, in Frick's (2013) study, handling risks related to musculoskeletal disorders, chemicals, and accidents were considered relevant in the public sector, too. 
During challenging OHS management situations, managers need supports and tools to meet their responsibilities. The employer, along with the developed organizational OHS procedures (e.g., risk assessment procedures and proactive activities for all risk types), should provide support to the managers. However, upper management personnel often ignore their legal duty, and they delegate the work environment issues to the frontline, without providing adequate resources or support (see Frick 2013).

Immediate superiors, colleagues, OHS and health care professionals, HR professionals, partners, and friends are some of the supports in place for managers. As well, other organizational procedures, such as the early on support model, help managers in challenging situations. Both a manager's own competence and resources and organizational support have an effect on successfully resolving challenging situations. Previous researches (Conchie et al. 2013; Frick 2013; Hardison et al. 2014) also identify the importance of the OHS resources, competence development, and organizational support needed for a manager to succeed in improving health and safety at work. To succeed in this, organizational OHS procedures, managers' resources and responsibilities as well as cooperation, conflict management, fair treatment, and collective rules should be emphasized in organizations.

According to the results of the study, the researched organizations had many obvious areas in need of development and support. The most important of these were the following:

- Support, guidance, induction, and complementary training for managers in relation to OHS management in the areas in which they have expressed clear support needs and shortcomings in their competencies (e.g., administration, evaluation of psychosocial burden and stress, challenging and difficult situations, providing feedback).

- Agreeing on and complying with common rules in OHS-related organizational procedures (e.g., appropriate work behavior, reduced workload, and remote work agreements).

- Intervening in organizational conflicts and any inappropriate and unprofessional behaviors.

- Active conflict management and resolution.

- Support from one's own supervisor (positive and constructive feedback, listening, being present and available, and providing encouragement, feedback, and motivation).

- Supporting employees' job-related self-determinations and reducing urgencies, excessive workloads, and different types of pressures.

A lack of or inadequate support from their own superior was a key challenge for some managers, as the principal support was expected to come from one's superior. If this was not possible, the difficult situations became burdensome when managers had to deal with the situation by themselves. In addition, peer support from colleagues was considered important. A formal peer support system could especially benefit less experienced managers, and supervisory work can be significantly aided by organizational procedures and practices being available, harmonized, and designed to serve the needs of the managers and the whole community. Organizational OHS procedures must be developed further so that the availability of support required by managers can be ensured when needed. For example, active cooperation between managers and occupational health care experts helps managers in handling employee psychosocial burdens and supports 
them in their supervisory work. Moreover, upper management support, resourcing, and guidance of OHS actions are crucial (see Frick 2013).

It is crucial to note the managers' positions, powers, and responsibilities as the employer's representative in relation to OHS. They are duty-bound by regulations to proactively assess and reduce all risks, and they must intervene in inappropriate behavior and harassment after having noticed or having otherwise become aware of such phenomena. Besides regulatory obligations, good OHS management and active conflict resolutions promote occupational well-being and achievements in performance objectives (see Leka et al. 2011). It is important to point out and enhance the managers' own understandings of the importance of their roles in managing OHS (see Idris et al. 2012), as well as their effects on both the OHS of the employees and the performance of the organization.

In the future, the competencies and collaborations of people and organizations will become even more important under constantly changing circumstances. Employers' representatives and managers working on the different levels of organizations play a central role in boosting the resources of the organization and promoting well-being. The skills and resources of managers, as well as the organizational support for supervisory work, affect the success of this task. Factors related to managing occupational well-being should not unreasonably increase the pressure on supervisors. Strengthening managers' resources and supporting supervisory work can positively influence the occupational well-being of the managers and the employees.

Research results focus on the central areas of dialogic leadership (Syvänen 2014a, $2014 b)$, namely the communication of organizational goals, procedures and rules, feedback, support, appreciation, collaboration, transformation, and conflict management. The dialogic approach is particularly tested in conflicting situations, and participantsespecially managers-should be skilled in the fundamentals of the dialogic approach. The dialogic leadership style provides managers with means and tools to process and solve difficult situations and manage conflicts in an open and dialogic manner. It also provides preconditions for positive work environments, employee well-being, and the enhancement of their work capabilities. Furthermore, the dialogic leadership approach prevents conflicts from arising when an open, participative, and interactive work community is actively promoted. However, conflicts and difficult individual behaviors often arise from inadequate resourcing and excessive workloads (Law et al. 2011), which must be controlled first.

Exploring the mutual expectations of the individuals in the work community with an open and dialogic approach, and, based on this, agreeing to common rules and principles of operation, improve trust and create clarity and transparency in organizations. Common rules provide all members of the work community, employees and managers alike, with available and mutually accepted supports to lean on in situations when individuals ignore these rules or behave inappropriately. It was surprising that the managers felt it was difficult to agree on common rules. The reason for this may be that agreeing on and drafting the rules together presumes an open discussion of the difficult factors that cause conflicts, pressures, and stresses.

Two independent researchers conducted this study on three organizations. The managers came from different sectors; had different professional backgrounds, managerial experiences, and organizational levels; and had varying work experiences. The managers were chosen at random. However, the results of the interviews and inquiries were quite consistent and easy to conjoin, which improves the validity of the study. 
In the construction sector, organizational supports, such as those from upper management, coworker forums, and training (Conchie et al. 2013), are key factors when helping managers to cope and succeed in OHS management. Also, previous studies in the construction sector and manufacturing industry argue there is a need to support managers' OHS roles and competences in order to genuinely improve OHS (e.g., Simola 2005; Tappura and Hämäläinen 2011; Törner and Pousette 2009). The results of this study reveal similar findings in the public service sector. Thus, the results are somewhat generalized for managerial work, but not necessarily for all industrial sectors. For example, in the manufacturing industry and construction sectors, occupational accidents may be the most challenging OHS problems.

\section{Conclusions}

Many current work environment issues, like PSWE problems, are complex, and few simple solutions exist or are in use. This study suggests that developing the resources, understandings, and competences of managers in relation to essential OHS issues may considerably improve the quality of working life, innovativeness, and performances of organizations. The results show that the most difficult OHS management situations in the organizations participating in the study were related to psychosocial risks. Organizational support is a key factor when helping managers succeed in OHS management, and backing up managers' resources and their supervisory work has a positive influence on the well-being of both the managers and their subordinates. These results provide guidance for employers, managers, researchers, and authorities in managing psychosocial risks in organizations, as well as signify their importance from both the OHS regulatory and performance points of view.

\section{References}

Alfredsson, L., Karasek, R. \& Theorell, T. (1982) 'Myocardial infarction risk and psychosocial work environment: An analysis of the male Swedish working force', Social Science \& Medicine 16(4): 463-467.

Amabile, T. M. (1997) 'Motivating creativity in organizations: On doing what you love and loving what you do', California Management Review 40: 39-58.

Amabile, T. M., Schatzel, E. A., Moneta, G. B. \& Kramer, S. J. (2004) 'Leader behaviors and the work environment for creativity: Perceived leader support', The Leadership Quarterly 15: 5-32.

Berger, A., Hartrick, C., Edelsberg, J., Sadosky, A. \& Oster, G. (2012) 'Economic costs of work and productivity losses in employees with osteoarthritis', Journal of Health \& Productivity 6(1): 24-31.

Björk, L., Szücs, S. \& Härenstam, A. (2014) 'Measuring capacity to perform across local government services-managers' perceptions', International Journal of Public Sector Management 27(1): 26-38.

Bluff, L. (2003) Systematic management of occupational health and safety. Working Paper 20, National Centre for OHS Regulation, Australian National University.

Bonde, J. P. (2008) 'Psychosocial factors at work and risk of depression: A systematic review of the epidemiological evidence', Occupational \& Environmental Medicine 65: 438-445. 
Bourgeois, L. (1981) 'On the measurement of organizational slack', Academy of Management Review 6: 29-39.

Boyd, C. (2003) Human Resource Management and Occupational Health and Safety. London: Routledge.

Bruhn, A. \& Frick, K. (2011) 'Why it was so difficult to develop new methods to inspect work organization and psychosocial risks in Sweden', Safety Science 49: 575-581.

Carder, B. \& Ragan, P. W. (2003) 'A survey-based system for safety measurement and improvement', Journal of Safety Research 34: 157-165.

Clarke, S. (2010) 'An integrative model of safety climate: Linking psychological climate and work attitudes to individual safety outcomes using meta-analysis', Journal of Occupational and Organizational Psychology 83: 553-578.

Clarke, S. \& Cooper, C. L. (2004) Managing the Risk of Workplace Stress: Health \& Safety Hazards. London: Routledge.

Conchie, S. M., Moon, S. \& Duncan, M. (2013) 'Supervisors' engagement in safety leadership: Factors that help and hinder', Safety Science 51: 109-117.

Cox, T. \& Griffiths, A. (2005) The nature and measurement of work-related stress. In J. Wilson $\&$ N. Corlett (eds.), Evaluation of Human Work: A Practical Ergonomics Methodology (pp. 553-573), third edition. Boca Raton, FL: CRC Press.

D 89/391/EEC. Council directive of 12 June 1989 on the introduction of measures to encourage improvements in the safety and health of workers at work.

Dana, D. (2001) Conflict Resolution. Sydney: McGraw-Hill.

De Jonge, J., Dollard, M. F., Dormann, C., Le Blanc, P. M. \& Houtman, I. L. D. (2000) 'The demand-control model: Specific demands, specific control, and well-defined groups', International Journal of Stress Management 7(4): 268-287.

DeJoy, D. M., Schaffer, B. S., Wilson, M. G., Vandenberg, R. J. \& Butts, M. M. (2004) 'Creating safer workplaces: assessing the determinants and role of safety climate', Journal of Safety Research 35: 81-90.

DeRango, K., Amick, B., Robertson, M., Rooney, T., Moore, A. \& Bazzani, L. (2003) The Productivity Consequences of Two Ergonomic Interventions. Upjohn Institute Working Paper No. 03-95. Kalamazoo, MI: W.E. Upjohn Institute for Employment Research.

Detert, J. R. \& Burris, E. R. (2007) 'Leadership behaviour and employee voice. Is the door really open?', Academy of Management Journal 50(4): 869-884.

Earnshaw, J. \& Cooper, C. L. (2001) Stress and Employer Liability. London: Institute of Personnel and Development.

Ertel, M., Stilijanow, U., Cvitkovic, J. \& Lenhardt, U. (2008) Social policies, infrastructure and social dialogue in relation to psychosocial risk management. In S. Leka \& T. Cox (eds.), The European Framework for Psychosocial Risk Management (pp. 60-78). I-WHO, Nottingham. [online 14.02.2014] Available: http:/www.ripsol.org/Data/ Elementos/467.pdf.

EU-OSHA (2007) Expert Forecast on Emerging Psychosocial Risks Related to Occupational Safety and Health. European Risk Observatory Report. European Agency for Safety and Health at Work. Luxembourg: Office for Official Publications of the European Communities.

EU-OSHA (2010) Mainstreaming OSH into business management. European Agency for Safety and Health at Work. Luxembourg: Office for Official Publications of the European Communities.

Eurofound (2010) European Working Conditions Survey-mapping the results. [online 14.02.2014] Available: http://www.eurofound.europa.eu/surveys/smt/ewcs/results.htm.

European Foundation (2007) European Foundation for the Improvement of Living and Working Conditions Fourth European Working Conditions Survey. Luxembourg: Office for Official Publications of the European Communities. 
Flin, R., Mearns, K., O’Connor, P. \& Bryden, R. (2000) ‘Measuring safety climate: Identifying the common features', Safety Science 34: 177-192.

Frantz, R. (1990) X-efficiency: Theory, Evidence and Applications. Second printing. Boston: Kluwer Academic Publishers.

Frick, K. (2013) 'Work environment dialogue in a Swedish municipality-Strengths and limits of the Nordic work environment model', Nordic Journal of Working Life Studies 3(1): 69-93.

Frick, K. \& Wren, J. (2000) Reviewing occupational health and safety management: Multiple roots and ambiguous outcomes. In: K. Frick, P. Jensen, M. Quinlan \& T. Wilthagen (eds.), Systematic Occupational Health and Safety Management. Perspectives on an International Development (pp. 17-42). Amsterdam: Pergamon.

Frick, K., Jensen, P., Quinlan, M., \& Wilthagen, T. (2000) Systematic OHS Management: Perspectives on an International Development. Oxford: Pergamon.

Gallagher, C., Underhill, E. \& Rimmer, M. (2001) Occupational Health and Safety Management Systems: A Review of their Effectiveness in Securing Healthy and Safe Workplaces. National Occupational Health and Safety Commission, Sydney, Australia, 71p.

George, J. M. (2008) Creativity in organizations. In: J. P. Walsh \& A. P. Brief (eds.), Annals of the Academy of Management 1: 439-477.

George, J. M. \& Zhou, J. (2007) 'Dual tuning in a supportive context: Joint contributions of positive mood, negative mood, and supervisory behaviors to employee creativity', Academy of Management Journal 50: 605-622.

Godin, I. \& Kittel, F. (2004) 'Differential economic stability and psychosocial stress at work: Associations with psychosomatic complaints and absenteeism', Social Science \& Medicine 58: 1543-1553.

Hale, A. R., Guldenmund, F. W., van Loenhout, P. L. C. H. \& Oh, J. I. H (2010) 'Evaluating safety management and culture interventions to improve safety: Effective intervention strategies', Safety Science 48: 1026-1035.

Hardison, D., Behm, M., Hallowell, M. R. \& Fonooni, H. (2014) 'Identifying construction supervisor competencies for effective site safety', Safety Science 65: 45-53.

Hasle, P., Hvid, H, Kristensen, T. S., Limborg, H. J., Møller, N., Pejtersen, J. \& Hvenegaard, H. (2008) Virksombedersindsats for et bedrepsykiskarbeidsmiliø (Enterprise actions for a better psychosocial work environment). Rapport fraforsknings projektet VIPS. København: NFA.

Hlobil, H., Uegaki, K., Staal, J. B., De Bruyne, M. C., Smid, T. \& Van Mechelen, W. (2007) 'Substantial sick-leave costs savings due to a graded activity intervention for workers with non-specific sub-acute low back pain', European Spine Journal 16(7): 919-924.

Hofmann, D. A. \& Stetzer, A. (1996) 'A cross-level investigation of factors influencing unsafe behaviours and accidents', Personnel Psychology 49: 307-339.

HSE (2007) Managing the Causes of Work-Related Stress. A Step-by-Step Approach using the Management Standards. Health and Safety Executive. HSE Books, second edition. [online 06.04.2014] Available: http://www.hse.gov.uk/pubns/priced/hsg218.pdf.

Idris, M. A., Dollard, M. F., Coward, J. \& Dormann, C. (2012) 'Psychosocial safety climate: Conceptual distinctiveness and effect on job demand and worker psychological health', Safety Science 50: 19-28.

Järvinen, P. (1998) Esimiestyö ongelmatilanteissa (Conflict Management). Helsinki: WSOY.

Karasek, R., Baker, D., Marxer, F., Ahlbom, A. \& Theorell, T. (1981) 'Job decision latitude, job demands, and cardiovascular disease: A prospective study of Swedish men', American Journal of Public Health 71(7): 694-705.

Kivimäki, M., Virtanen, M., Elovainio, M., Kouvonen, A., Väänänen, A. \& Vahtera, J. (2006) 'Work stress in the aetiology of coronary heart disease-A meta-analysis', Scandinavian Journal of Work, Environment \& Health 32(6): 431-442. 
Köper, B., Möller, K. \& Zwetsloot, G. (2009) 'The Occupational Safety and Health Scorecard-a business case example for strategic management', Scandinavian Journal of Work, Environment \& Health 35(6): 413-420.

L 23.08.2002/738. Työturvallisuuslaki (Occupational Safety and Health Act). [online 14.02.2014] Available: http://www.finlex.fi/en/laki/kaannokset/2002/en20020738.pdf (unofficial translation).

Law, R., Dollard, M. F., Tuckey, M. R. \& Dormann, C. (2011) 'Psychosocial safety climate as a lead indicator of workplace bullying and harassment, job resources, psychological health and employee engagement', Accident Analysis \& Prevention 43: 1782-1793.

Leibenstein, H. (1969) 'Organizational or frictional equilibria, X-efficiency, and the rate of innovation', Quarterly Journal of Economics 83(4): 600-623.

Leibenstein, H. (1987) Inside the Firm: The Inefficiencies of Hierarchy. Harvard: Harvard University Press.

Leka, S., Jain, A., Widerszal-Bazyl, M., Zołnierczyk-Zreda, D. \& Zwetsloot, G. (2011) 'Developing a standard for psychosocial risk management: PAS 1010', Safety Science 49: 1047-1057.

Lundberg, U. \& Melin, B. (2002) Stress in the development of musculoskeletal pain. In S. Linton (ed.), Avenues for the Prevention of Chronic Musculoskeletal Pain and Disability (pp. 165-179). Amsterdam: Elsevier Science.

Natali, E., Deitinger, P., Rondinone, B. \& Iavicoli, S. (2008) Exploring stakeholders' perceptions on social policies, infrastructures and social dialogue in relation to psychosocial risks. In S. Leka, \& T. Cox (eds.), The European Framework for Psychosocial Risk Management: PRIMA-EF (pp. 79-95). Nottingham, UK: I-WHO Publications.

Nelson, A., Matz, M., Chen, F., Siddharthan, K., Lloyd, J. \& Fragala, G. (2006) 'Development and evaluation of a multifaceted ergonomics program to prevent injuries associated with patient handling tasks', International Journal of Nursing Studies 43(6): 717-733.

Nielsen, K., Randall, R., Holten, A.-L. \& González, E. R. (2010) ‘Conducting organizationallevel occupational health interventions: What works?’, Work \& Stress 24: 234-259.

Niemelä, R., Rautio, S., Hannula, M. \& Reijula, K. (2002) 'Work environment effects on labor productivity: An intervention study in a storage building', American Journal of Industrial Medicine 42(4): 328-335.

OHSAS 18001:2007 Occupational Health and Safety Management Systems-Requirements. London: OHSAS Project Group BSI.

Patton, M. Q. (2001) Qualitative Research \& Evaluation Methods. Utilization-Focused Evaluation. Third Edition. Saint Paul, MN: SAGE Publications.

Safety in numbers (2003) Pointers for a Global Safety Culture at Work. Geneva: International Labour Organization, $27 \mathrm{p}$.

Saksvik, P. O. \& Quinlan, M. (2003) 'Regulating systematic occupational health and safety management: Comparing the Norwegian and Australian experience', Relations Industrielles 58: 33-59.

Saksvik, P. Ø., Nytrö, K., Dahl-Jørgensen, C. \& Mikkelsen, A. (2002) 'A process evaluation of individual and organizational occupational stress and health interventions', Work \& Stress 16(1): 37-57.

Salminen, S., Saari, J., Saarela, K. L. \& Räsänen T. (1993) ‘Organizational factors influencing serious occupational accidents', Scandinavian Journal of Work, Environment \& Health 19(5): 352-357.

Schabracq, M., Winnubst, J. \& Cooper, C. (1996) Handbook of Work and Health Psychology. New York: John Wiley.

Siegrist, J., Starke, D., Chandolab, T., Godinc, I., Marmot, M., Niedhammer, I. \& Peter, R. (2004) 'The measurement of effort-reward imbalance at work: European comparisons', Social Science \& Medicine 58(8): 1483-1499. 
Sievänen, M., Nenonen, N. \& Hämäläinen, P. (2013) The economic impacts of occupational health and safety interventions-A critical analysis based on the nine-box model of profitability. In Proceedings of the $45^{\text {th }}$ Nordic Ergonomics \& Human Factors Society Conference NES2013, Reykjavik, Iceland.

Simola, A. (2005) Turvallisuuden johtaminen esimiestyönä. Tapaustutkimus pitkäkestoisen kehittämishankkeen läpiviennistä teräksen jatkojalostustehtaassa (Safety leadership as a line supervisor's task. A case study of the implementation of a long-term development project at a steel works), Dissertation, University of Oulu, 269 p. [online 14.02.2014] Available: http://herkules.oulu.fi/isbn9514277619/isbn9514277619.pdf (in Finnish).

Singh, J. V. (1986) 'Performance, slack, and risk taking in organizational decision making', Academy of Management Journal 86(29): 562-585.

Sutherland, V. \& Cooper, C. L. (1991) Stress and Accidents in the Offshore Oil and Gas Industry. Houston, TX: Gulf Publishing.

Syvänen, S. (2010) Evil eleven syndrome. Dark side of workplaces. Pressures at work and costs of non-interference, Doctoral dissertation, University of Tampere, School of Management. VDM Verlag Dr. Saarbrücken: Müller Aktiengesellschaft \& Co.

Syvänen, S. (2014a) Dialogic leadership and participatory development: Key factors of quality of working life and performance. In O. Broberg, N. Fallentin, P. Hasle, P. L. Jensen, A. Kabel, M. E. Larsen \& T. Weller (eds.), Human Factors in Organizational Design and Management-XI \& Nordic Ergonomics Society Annual Conference-46. Selected and peer reviewed papers from ODAM/NES Conference (pp. 397-402), Copenhagen, Denmark. Santa Monica CA, USA: IEA Press.

Syvänen, S. (2014b) Dialogisen johtamisen avaimia (The Keys of dialogic leadership). In T. Pakarinen and T. Mäki (eds.), Henkilöstöjohtaminen kurkiauran kärkeen. Uudistumisen sykettä palveluibin (pp. 204-216), Helsinki: Edita.

Syvänen, S. \& Kokkonen, A. (2011) Hyvinvointia vanhuksille ja työn iloa henkilöstölle. Ytyä Länteen hankkeen tulokset ja opetukset ybteistoiminnallisesta työybteisöjen kehittämisestä (Well-being for the elderly and joy of work for the personnel. Results and lessons from the cooperative workplace development project on the productivity and well-being at work in the services for the elderly). Helsingin kaupungin sosiaaliviraston julkaisusarja. Oppaita ja käsikirjoja. (Helsinki Social Services, Guidebooks) 12/2011. [online 14.02.2014]Available:http://www.tsr.fi/tutkimustietoa/tata-on-tutkittu/hanke/?h= 110451\&n=aineisto (in Finnish).

Syvänen, S., Kasvio, A., Loppela, K., Lundell, S., Tappura, S. \& Tikkamäki, K. (2012) Dialoginen johtaminen innovatiivisuuden tekijänä. tutkimusohjelman teoreettiset lähtökohdat, tutkimuskysymykset ja toteutus (Dialogic leadership as a factor of innovativeness. Theoretical starting points, research questions and implementation of the research programme), Työterveyslaitos (Finnish Institute of Occupational Health), Helsinki: PrintserviceOy. [online 14.02.2014] Available: http://www.ttl.fi/fi/verkkokirjat/Documents/Dialoginen_ johtaminen.pdf (in Finnish).

Tappura, S. \& Hämäläinen, P. (2011) Promoting occupational health, safety and well-being by training line managers. In J. Lindfors, M. Savolainen \& S. Väyrynen (eds.), Proceedings of the 43 ${ }^{\text {th }}$ Annual Nordic Ergonomics Society Conference NES 2011 (pp. 295-300), Oulu, Finland. [online 14.02.2014] Available: http://www.kotu.oulu.fi/nes2011/docs/ Proceedings_NES2011_Oulu.pdf.

Tappura, S. \& Hämäläinen, P. (2012) The occupational health and safety training outline for the managers. In P. Vink (ed.), Advances in Social and Organizational Factors, Advances in Human Factors and Ergonomics Series, Vol. 9 (pp. 356-365). Taylor and Francis, CRC Press. [online 14.02.2014] Available: http://www.crcnetbase.com/doi/pdf/10.1201/b12314-44.

Tappura, S. \& Syvänen, S. (2013a) Managing occupational health and safety in expert organisations. In Proceedings of the $45^{\text {th }}$ Annual International Conference of the Nordic Ergonomics and Human Factors Society NES 2013, Reykjavik, Iceland. 
Tappura, S. \& Syvänen, S. (2013b) Kestävää työelämää edistävä työturvallisuuden johtaminen (Occupational safety and health management promoting sustainable working life). In M. Virkajärvi (ed.), Proceeding of the Work Research Conference 4/2013 (pp. 292-305), Work Research Centre, University of Tampere.

Tappura, S., Sievänen, M., Heikkilä, J., Jussila, A. \& Nenonen, N. (2014) ‘A management accounting perspective on safety', Safety Science (in press).

Theorell, T. \& Karasek, R. A. (1996) 'Current issues relating to psychosocial job strain and cardiovascular disease research', Journal of Occupational Health Psychology 1(1): 9-26.

Tomer, J. F. (1987) Organizational Capital: The Path to Higher Productivity and Well-being. New York: Praeger.

Törner, M. \& Pousette, A. (2009) 'Safety in construction-A comprehensive description of the characteristics of high safety standards in construction work, from the combined perspective of supervisors and experienced workers', Journal of Safety Research 40: 399-409.

Tulonen, T. (2010) Electrical accident risks in electrical work. Tukes-Publication 2/2010. Tukes (The Finnish Safety and Chemicals Agency), Helsinki.

Työterveyslaitos (2013). Työ ja terveys Suomessa 2012. Seurantatietoa työoloista ja työhyvinvoinnista (Work and health in Finland 2012. Workplace conditions and well-being based on the Work and Health Survey). Työterveyslaitos (Finnish Institute of Occupational Health). Tampere: TammerprintOy. [online 14.02.2014] Available: http:/www.ttl.fi/fi/verkkokirjat/ tyo_ja_terveys_suomessa/Documents/Tyo_ja_Terveys_2012.pdf (in Finnish).

Vahtera, J., Kivimäki, M., Pentti, J. \& Theorell, T. (2000) 'Effect of change in the psychosocial work environment on sickness absence: a seven year follow up of initially healthy employees', Journal of Epidemiology \& Community Health 54: 484-493.

Yeow, P. H. \& Sen, R. N. (2003) 'Quality, productivity, occupational health and safety and cost effectiveness of ergonomic improvements in the test workstations of an electronic factory', International Journal of Industrial Ergonomics 32(3): 147-163.

Zohar, D. (2002) 'Modifying supervisory practices to improve sub-unit safety. A leadershipbased intervention model', Journal of Applied Psychology 87: 156-163.

\section{End notes}

${ }^{1}$ The submitted article draws to some extent on a translation of the following articles published in Finnish:

Tappura, S. \& Syvänen, S. (2013) Occupational Safety and health management promoting sustainable working life (Original Finnish title: Kestävää työelämää edistävä työturvallisuuden johtaminen). In M. Virkajärvi (ed.), Proceeding of the Work Research Conference 4/2013 (pp. 292-305), Work Research Centre, University of Tampere, Finland.

Syvänen, S. \& Tappura, S. (2014) Challenging management situations and needs for support in supervisory work (Original Finnish title: Vaikeat johtamistilanteet ja tuen tarve esimiestyössä). In M. Virkajärvi (ed.), Proceeding of the Work Research Conference 5/2014 (pp. 313-324), Work Research Centre, University of Tampere, Finland. 